\title{
Investigation of International News Sites in the Context of Neutrality in the News: The Example of Turkey's Peace Spring Operation
}

\author{
Ekrem Çelikiz
}

Fine Art Faculty, Harran University, Şanlıurfa, Turkey

\begin{tabular}{|c|c|}
\hline ARTICLE INFO & ABSTRACT \\
\hline $\begin{array}{l}\text { Keywords: } \\
\text { News } \\
\text { Internet reporting } \\
\text { Television reporting } \\
\text { Discourse analysis } \\
\text { International Media } \\
\text { Turkey's Peace Spring } \\
\text { Operations }\end{array}$ & $\begin{array}{l}\text { Internet journalism has brought a new impetus to journalism. The } \\
\text { events in the world are instantly transferred to the reader / viewer on } \\
\text { television channels, social media and internet news sites. There is a } \\
\text { rivalry between the media tools at the speed of the transfer of news. } \\
\text { International media organizations belonging to different capital } \\
\text { groups, while conveying the news to the audience / reader in a fast } \\
\text { manner, occasionally violating the reporting criteria; they ignore the } \\
\text { principles of neutrality in the news. Specially, international media } \\
\text { organizations often violate the principles of impartiality in their news } \\
\text { when broadcasting news about different countries. } \\
\text { In this study, we will investigate how the news websites of different } \\
\text { countries, CNN International, France } 24 \text {, Al Jazeera, TRT World and } \\
\text { BBC news portals convey Turkey's Peace Spring Operation to their } \\
\text { readers in } 2019 \text { in the context of the principles of neutrality in the } \\
\text { news. A discourse analysis method will be used in the study. }\end{array}$ \\
\hline
\end{tabular}

\section{Introduction}

One of the most important principles of news transmission is the principle of impartial and accurate reporting of news.

In a globalizing world, it is also important to transfer news quickly.

Events occurring in different countries should be transmitted to the viewer/reader/listener in an instant, accurate and impartial manner. In practice, however, media outlets belonging to different capital groups can ignore the principles of neutrality in news.

While international media outlets based in different countries are also transmitting an event that happened in one country, they are transmitting the news to the viewer/reader based on the foreign policy perspective of the country they belong to.

In order to secure Turkey's own border and to send 3.5 million Syrians who have settled in Turkey back to their home countries, have made peace springs of action; news was prepared in different ways in international media organs, and news was conveyed in parallel with the foreign policies of the countries where the media organs were established, ignoring the principles of impartiality.

Peace Spring Operatiin, launched by the Turkish Republic against ISIL and pkk/PYD terror organizations in northern Syria, has been transformed into a perception operation in international media outlets. And the principles of neutrality and objectivity in news coverage have been moved away.

In this study, we will examine how Turkey's peace fountain operation in northern Syria is presented in international media outlets based in different countries.

* Corresponding Author E-Mail Address: ekremcelikiz@gmail.com 


\section{Basic Definition:}

With the developing technology, the habit of following the news over the internet has become widespread. The rapid spread of the news over the internet has led to the discussion of the principles of truthfulness and impartiality in the news.

Many internet news portals serve hundreds of news to the world every day, ignoring the principles of accuracy and impartiality in news.

Accurate, fast and impartial transmission of news is as important as the speed of news. Every day thousands of false, asparagus, fabricated news from different countries are served all over the world. Getting the right news from the wrong news is becoming more and more difficult every day.

The subject of objectivity in news is frequently discussed in journalism. The word "objective a used in return for objectivity in Turkish is of French origin. Objectivity is very important in the collection, writing and publication of the news. Objectivity is reminiscent of objectivity and accuracy. There is no place for individual opinions, biased approaches and judgments in the news (Bülbül, 2000: 209).

When writing a story, it is important to write the story in neutral language.

Objectivity in the news includes the principles of keeping the journalist's own tendencies out of the text and reflecting the news in the way it is, not giving place to enthusiasm, and avoiding publications that affect the judiciary. Objectivity is a counterpoint to neutrality and tendency (Çakır, 2007: 126).

This can be achieved by producing news that is enriched and understood by the contributions of a well-trained, cultured, honest and competent journalist (Girgin, 1998: 24).

In some cases, the public is misinformed and the news is served by being distorted. This situation is called "distotion" or "disinformation" in the news. Distortions, in general, are often seen in outside News. Biased reporting in accordance with the foreign policies of countries is often a recurring method. Economic, ideological and political interests are also at the heart of the news, which is prepared in accordance with and in line with foreign policies. Developed countries are generally biased towards underdeveloped or developing countries. The media outlets of developed countries choose the news data of underdeveloped and developing countries mostly from the negative issues such as war, epidemics and natural disasters. In the internal news, distortions are mostly seen between the government and the opposition in politics and the rival organizations in the business world (Bülbül: 2001b: 289 - 290).

In order to avoid making mistakes in the news, it is necessary to avoid doubting the accuracy of the news. The accuracy of the news means the accuracy of the information and documents collected. As reporting is a fast endeavor, it is sometimes seen that inexperienced reporters write the news without performing the control of the information they obtain and publish it in the name of news circumvention. However, journalistic responsibility requires that in no case should information or documents be published that have doubts about their accuracy (Yüksel and Gürcan, 2001: 77)

Every knowledge has its source. The information obtained for the news must also have a source. That is why the main purpose of the reporter running the news is to provide accurate information. In investigating the truth, he must investigate the accuracy of the information he reveals. The source of information not certain should not be transferred (Aslan, 2002: 61)

Manipulation is a word of French origin; in Turkish, it means "orientation" as its word counterpart. Manipulation is the job of directing a phenomenon toward a goal, toward that goal, or toward another goal. Manipulation has three accepted meanings: 1. don't influence people outside their knowledge or when they don't want to, 2. changing information by selecting, adding and subtracting, 3 . the job of using assets in a constructive, descriptive and useful way. The meaning considered to be" orientation "suggests integration with the meaning of" orientation for interest" in communication sciences. Also, manipulation is a psychological 
warfare technique. In psychological warfare, concepts are emptied, new meanings are loaded onto them. Something that is good is bad; something that is bad can also be shown as good (Çakır, 2007: 87 - 88).

Manipulation is also against the ethics and freedom of the press. In practice, there are usually two areas of manipulation: A) the reporter who writes the news is interfered with. b) the press organ that will publish the news is being interfered with. Manipulation is more common in the holding press and in the case of monopolization (Bülbül, 2001b: 290).

It is often seen in international news channels that the news is manipulated.

While objectively the opinions of all the parties involved in the news should be given in a balanced way, many international news channels and media portals do not comply with this rule.

\section{Discourse Analysis Application}

In this study, how international news portals based in different countries present Turkey's peace Springs operation to the north of Syria in the news were examined by Discourse Analysis.

CNN from USA, BBB from UK, France24 from France, Aljazeraa from Qatar, and Trtworld from Turkey were selected as samples.

October 9, 2019 and October 10, 2019, which are the dates when Turkey started operations, were compared and examined by comparing the news about the operation in different country's press.

\section{1. $C N N$}

CNN television and news website is a media organization with an emphasis on international news broadcasts broadcast from the United States. News about Turkey's "peace Spring operation" in northern Syria has also appeared in this media organization.

Turkey's operation on CNN News portal is given in the news as follows:

"Turkey launches military offensive in Syria, days after Trump announced pullback of US troops"

"Turkey began a planned military offensive into northeastern Syria on Wednesday, launching airstrikes and artillery fire across the border just days after the Trump administration announced it was pulling US troops back from the area.

The operation is aimed at pushing Kurdish forces -- who were a key ally of the US in the fight against ISIS -- away from Turkey's border."

The CNN news site reported on Turkey's operation to the north of Syria; emphasized that the operation began after the U.S. withdrew its troops from the north of Syria and emphasized that Turkey's aim in the operation was to drive Kurdish groups, which are allies of the United States and are fighting ISIS, away from the border.

Turkey announced the operation not against Kurdish groups, but against the pkk/PYD, which is part of Kurdish groups and which the West considers a terrorist organization, but this statement was not included in the news and the news was prepared and published in accordance with the foreign policy of the United States

(https://edition.cnn.com/2019/10/09/politics/syria-turkey-invasion-intl-hnk/index.html)

Other headlines and news flash related to Turkey's operation in northern Syria on CNN are as follows:

"State official: Trump tasked State with trying to broker a ceasefire"

The report was based on the US official, emphasizing that the US president is trying to mediate for the ceasefire.

"Senior State Department official: "I'm extremely distressed" about Turkish military operation" "Trump says sanctions possible on Turkey" 
In these headlines, only the theses of the United States were brought to the fore in the news. Official statements of the Turkish state did not appear in the news.

"Norway suspends new arms sales applications to Turkey and calls for end to Turkish military operation"

"US Ambassador says Trump didn't endorse Turkey's military action into Syria"

"European nations call on Turkey to cease unilateral military action in Syria"

"France summons Turkish ambassador over Syria offensive"

"More than 60,000 people displaced in northeastern Syria"

"Macron say Turkish offensive risks recreating ISIS caliphate"

"Syrian National Army says 13 rival Kurdish fighters killed in Turkish military offensive"

Turkey's comments about the operation in northern Syria, Turkey's thesis, did not appear in the news headlines. CNN reported the news from the perspective of U.S. foreign policy and U.S. government officials. According to the principles of impartial reporting, the statements of the Turkish government should have been made in the news, but CNN did not comply with these principles.

(https://edition.cnn.com/middleeast/live-news/syria-turkey-military-offensive-dleintl/index.html)

\subsection{France 24}

France 24 television is a media organization based in France that broadcasts international news. News about Turkey's operation in northern Syria has also been published on this media portal. "Turkey launches air and ground military operations against Kurds in northern Syria"

Turkey announced Wednesday that it had launched military operations against Kurdish forces in northern Syria, first with air strikes and then with a ground offensive, prompting thousands of civilians to flee the region. The UN Security Council will hold a closed-door meeting on the crisis on Thursday.

France 24 television also used a headline in the news that excludes Turkey's arguments in the operation launched by Turkey in northern Syria. France 24 has highlighted reports that Turkey's operation is aimed at Syrian Kurds. He emphasized in the news that thousands of civilians had left the area and highlighted in the news that the UN was closely following Turkey's operation. Again, this news portal did not mention Turkey's reasons for the operation in the news. The news portal and TV channel, which should be objective, have ignored the rules of objectivity in the news and have not impartially transmitted the news to the audience.

(https://www.france24.com/en/20191009-turkey-launches-operation-against-kurds-innorthern-syria-erdogan-says-1)

"Syrian Kurds claim they repelled new Turkish ground offensive"

"Kurdish forces said they pushed back a fresh Turkish ground attack in northeastern Syria Thursday, a day after Ankara launched a cross-border assault that has drawn international condemnation."

"Tens of thousands fled Turkish offensive in less than 24 hours, Syrian rights group says" "More than 60,000 people have already fled areas in northeast Syria, the London-based Syrian Observatory for Human Rights said Thursday, less than 24 hours after Ankara launched an offensive in the region". (https://www.france24.com/en/20191010-tens-of-thousands-fledturkish-offensive-in-less-than-24-hours-syrian-rights-group-says-1)

France 24 reported that the Syrian Kurds had resisted Turkey's operation, emphasized that Turkey's operation had caused thousands of civilians to emigrate, and did not give any information about the Turkish side in the news. 


\subsection{AL Jazarea:}

Is a Qatar-based broadcasting international media organization. There have been numerous reports about Turkey's operation in northern Syria.

"Eight dead in blast in Turkish-held Syrian town"

"Ankara blames bomb attack in the northeastern town of Tal Abyad on Kurdish fighters."

(https://www.aljazeera.com/news/2019/11/dead-blast-turkish-held-syrian-town-

191110181901516.html)

Al Jazeera, Turkey's operation in the Region 8 people killed as a result of bomb blast has been brought to the fore in the news. The Turkish Republic has stressed in news reports that Kurdish fighters are responsible for the blast.

"Turkey deports US national as it starts returning ISIL fighters"

"Turkish official says seven German nationals will be returned on November 14, according to state media."

Al Jazeera has made it clear in the news that members of ISIS will be sent to their home countries, where they are citizens, in Turkey's operation. The views of the Turkish state have come to the fore in more news.

(https://www.aljazeera.com/news/2019/11/turkey-deports-national-starts-returning-isil-

fighters-191111085045352.html)

Turkey-Syria border: All the latest updates

"Turkish troops cross Syrian border east of the Euphrates River as UN expresses 'alarm' over Ankara's military push."

"Turkey has launched a military operation in northeast Syria."

"President Recep Tayyip Erdogan says the offensive - which began with air raids on Wednesday - is aimed at removing Kurdish-led forces from the border area and creating a "safe zone" to which millions of Syrian refugees can be returned."

Al Jazeera, Türkiye'nin Suriye'nin kuzeyine yapmış olduğu operasyonun gerekçesini, Türkiye Cumhuriyetinin Cumhurbaşkanının görüşlerini haberde ön plana çıkarak aktarmıştır. Türkiye'nin operasyon gerekçeleri haberlerde ön plana çıkartılmıştır.

Al Jazeera cited the rationale for Turkey's operation in northern Syria, citing the views of the president of the Republic of Turkey in the news. Turkey's reasons for the operation have been highlighted in the news.

(https://www.aljazeera.com/news/2019/10/turkey-syria-border-latest-updates191008131745495.html)

"Thousands of civilians flee from border areas as Turkey presses assault against Kurdish forces for second straight day."

"Turkey has launched a major military operation in northeast Syria."

President Recep Tayyip Erdogan says the offensive is aimed at removing Kurdish-led forces from the border area and creating a "safe zone" so millions of Syrian refugees can be returned. (https://www.aljazeera.com/news/2019/10/turkey-military-operation-syria-latest-updates191010061648676.html)

Al Jazeera reported that Syrian asylum seekers living in Turkey would be sent back to their home countries. Turkey's official theses have been highlighted in the news.

However, the word "terrorist" was not used in Aljazeera media portals for Kurds with PYD, which Turkey considers to be a continuation of the PKK, and the word "Kurdish Warrior" was used for Kurds with PYD. 


\subsection{TRT World}

TRT World Television is an international media organization based in Turkey. Many reports have been published about Turkey's operation in northern Syria.

"Car bomb attack kills at least eight civilians in Syria's Tal Abyad"

Türkiye'nin operasyon yaptığı bölgede araçla yapılan bombalı saldırı haber olarak yer almıştır. A car bomb attack has been reported in Turkey's area of operation.

(https://www.trtworld.com/middle-east/car-bomb-attack-kills-at-least-eight-civilians-in-syrias-tal-abyad-31269)

"Twitter reactions to Turkey's Operation Peace Spring"

"Turkey has begun the fight against PKK/PYD terrorists in northern Syria following US President Donald Trump's announcement that the US is pulling its troops from the region." (https://www.trtworld.com/turkey/twitter-reactions-to-turkey-s-operation-peace-spring30484)

Turkey's operation in northern Syria against the PKK/PYD terrorists has been highlighted in the news and the operation began immediately after the United States withdrew its troops from the region.

TRT World has highlighted Turkey's own official theses in the news.

"US Senate bipartisan effort against Turkey a reaction, not a solution"

(https://www.trtworld.com/turkey/us-senate-bipartisan-effort-against-turkey-a-reaction-nota-solution-30495)

"Turkeys Jewish Coomunity supports unti- terror campaigne in syria"

"Jewish and Christian communities in Turkey support Turkey's attempts to liberate northeastern Syria from terrorist groups."

(https://www.trtworld.com/turkey/turkey-s-jewish-community-supports-anti-terror-campaignin-syria-30510)

It has been highlighted in the news that Jews and Christians living in Turkey are supporting Turkey's operation.

Is it worth jeopardising the US-Turkey alliance for the sake of the YPG?

While its NATO ally Turkey has repeatedly offered military assistance to the US to help defeat Daesh, Washington still sided with a terror group affiliate the YPG, endangering a decades-old partnership.

In this report, TRT World highlighted the fact that the US, a NATO ally, should act together with Turkey and should not act with pkk/PYD terrorists in Syria. A report reflecting Turkey's theses has been prepared.

(https://www.trtworld.com/magazine/is-it-worth-jeopardising-the-us-turkey-alliance-for-thesake-of-the-ypg-30514)

\section{5. $B B C$}

$\mathrm{BBB}$ is a UK-based broadcasting media organisation. There have been numerous reports on Turkey's peace spring operation in northern Syria on the BBC.

"Turkey-Syria incursion 'risks the security of IS prison camps""

"US Defence Secretary Mark Esper says he is "greatly disappointed" by Turkey's decision to mount an offensive on Kurdish-held areas of northern Syria."

The BBC reports on Turkey's operation in northern Syria, highlighted that Turkey's operation in Syria risks the escape of ISIS prisoners.

In the flash of the news, was given the statements of the US Secretary of Defense.

(https://www.bbc.com/news/av/world-middle-east-50021699/turkey-syria-incursion-risksthe-security-of-is-prison-camps) 
"Turkey offensive: Erdogan spokesman defends new campaign"

"A senior adviser to President Recep Tayyip Erdogan has defended Turkey's offensive in northern Syria.

In an interview with the BBC, Ibrahim Kalin said a "safe zone" was needed to protect Turkey and allow Syrian refugees to return.

He added that the operation would not diminish efforts against Islamic State - also known as Daesh."

(https://www.bbc.com/news/av/world-middle-east-49989759/turkey-offensive-erdogan-

spokesman-defends-new-campaign)

In this report, the BBC reported Turkey's own theses in the news with an interview with the President's spokesman Ibrahim Kalin.

“Turkey Syria offensive: Will Islamic State re-emerge?

(Yes, quite possibly, in some form, is the short answer. Jihadist groups like Islamic State (IS) and al-Qaeda thrive on chaos and disruption. This incursion threatens to bring both to a region that was already a tinderbox of tension.

But the outcome will partly depend on the depth, duration and intensity of the Turkish incursion into Syria. )"

The BBC has stressed in news reports that Turkey's operation could resurface the danger of ISIS.

(https://www.bbc.com/news/world-middle-east-49998940)

“Turkey Syria offensive: 'The Kurds have no friends but the mountains'

Why is Turkey bombing the Kurds in Syria?

Tens of thousands of people have fled their homes in northern Syria, as Turkish forces step up their cross-border offensive on Kurdish-held areas.

International clamour has increased for Turkey to halt the attack.

The BBC's Martin Patience explains what's behind the conflict."

BBC News reports portrayed the pkk/ypg as Kurds and made the statements of the Kurds into headlines. Turkey's operation brought to the fore in the news that thousands of civilians had emigrated.

(https://www.bbc.com/news/av/world-middle-east-50009345/why-is-turkey-bombing-thekurds-in-syria)

\section{World Reaction}

country where the official announcement of the examined media portals have made about the operation by Turkey into northern Syria is remarkable.

The news on the media portals coincide with the official statements of the countries.

\section{1. $E U$}

EU chief Jean-Claude Juncker demanded Turkey to halt its military operation, telling Ankara the bloc would not pay for any so-called "safe zone" that might be created.

The EU's top foreign policy official, Federica Mogherini warned that "unilateral action on Turkey's part threatens" concerted action by the West and Turkey and other countries to defeat ISIL.

Turkish military action, she said, risked "protracted instability in northeast Syria, providing fertile ground for the resurgence of Daesh". 


\subsection{United States}

US President Donald Trump said Turkey's air assault was "a bad idea" not backed by the United States, and called on Ankara to protect religious minorities.

"The United States does not endorse this attack and has made it clear to Turkey that this operation is a bad idea," Trump said in a statement released by the White House.

"Turkey has committed to protecting civilians, protecting religious minorities, including Christians, and ensuring no humanitarian crisis takes place - and we will hold them to this commitment."

\subsection{UK}

British Foreign Secretary Dominic Raab said in a statement he had "serious concerns about the unilateral military action that Turkey has taken".

"This risks destabilising the region, exacerbating humanitarian suffering, and undermining the progress made against Daesh which should be our collective focus."

France

French Foreign Minister Jean-Yves Le Drian said on his Twitter feed that the operation "is jeopardising the anti-Islamic State coalition's security and humanitarian efforts and is a risk for the security of Europeans. It has to end."

French Defence Minister Florence Parly said that the Turkish offensive is dangerous and should stop.

"[It is] dangerous for the security of the Kurds. Dangerous because it benefits Islamic State, which we have been fighting for five years. It must stop," Parly wrote on Twitter.

\subsection{Qatar}

The Qatari government has made statements in support of Turkey's operation in northern Syria. Qatar-based broadcaster Al Jazeraa TV and the news portal have also highlighted the government's views.

\subsection{TURKEY}

The Turkish government has declared that the operation in northern Syria is not aimed at Kurds living in Syria, but at terrorists from the YPG, the Syrian branch of the PKK, which all Western countries regard as terrorists.

Turkey also explained that one of the objectives of the operation was to establish a safe zone for Syrian asylum seekers living in Turkey and to relocate them.

\section{Conclusion}

With the development of technology, journalism has undergone a change. Traditional media is being replaced by New Media tools today.

With the spread of new media, it has become more important to protect the principles of truthfulness and impartiality in journalism.

It has become quite easy to prepare a news story over the Internet and quickly serve it to the whole world. A lot of News called asparagas, which are not real and are not based on any source, are served to all countries of the world.

News should be transmitted to the audience in a truthful, impartial manner. The most important of the news principles is the impartial transmission of news. Today, however, many media organizations do not apply the principles of impartial reporting, in violation of the principles of reporting.

International TV channels, news portals often prepare news in accordance with the political views and foreign policy of the country in which they are based. 
When writing a news story, the opinions of all parties involved should be given in the news in an objective way, but usually the news is prepared unilaterally.

The internationally published news portals we examined in the study did not generally adhere to the principles of impartial reporting. Each media body served the news in line with the foreign political views of its native country and the views of the ruling political parties.

International news portals and TV channels are required to equally write their views about the parties involved in the news. The principles of impartial reporting should also be applied in practice.

The 5 news portals and the news that were examined did not comply with the principles of neutrality and the views of the countries in which they were resident were repeated in the news.

\section{References}

Aslan, Kemal (2002). Road Map of News (I. Printing). Istanbul: Key Books.

Bülbül, Ridvan (2000). General Journalistic Information (I. Printing). Ankara: Nobel Publications.

Bülbül, Ridvan (2001) Communication and Ethics (2. Printing). Ankara: Nobel Publications.

Çakır, Hamza (2007). Introduction to Journalism (I. Printing). Konya: Tablet Publications.

Çelikiz, E. (2018). TV journalism in the context of balance: 2014 Turkish presidential election sample unpublished doctoral thesis - Istanbul University

Girgin, Atilla (1998News Writing Techniques. Istanbul: Revolution Bookstore

Yüksel, Erkan ve Gürcan, Halil İbrahim (2001). The Messenger's Manual. Eskişehir: Anadolu University publications: no.1263. 